\title{
Streptomyces specialis sp. nov.
}

Correspondence
Peter Kämpfer
peter.kaempfer@umwelt.uni-
giessen.de

Correspondence giessen.de

\section{Peter Kämpfer, ${ }^{1}$ Birgit Huber, ${ }^{2}$ Sandra Buczolits, ${ }^{2}$ Kathrin Thummes, ${ }^{1}$ Iris Grün-Wollny ${ }^{3}$ and Hans-Jürgen Busse ${ }^{2}$}

\author{
${ }^{1}$ Institut für Angewandte Mikrobiologie, Justus-Liebig-Universität Giessen, D-35392 Giessen, \\ Germany \\ ${ }^{2}$ Institut für Bakteriologie, Mykologie und Hygiene, Veterinärmedizinische Universität, A-1210 Wien, \\ Austria \\ ${ }^{3}$ Labor Grün-Wollny, D-35394 Giessen, Germany
}

A Gram-positive, non-endospore-forming bacterium (GW41-1564 $4^{\top}$ ) was isolated from soil. Comparison of $16 \mathrm{~S}$ rRNA gene sequences showed that strain GW41-1564 ${ }^{\mathrm{T}}$ is a member of the genus Streptomyces, exhibiting highest similarities with Streptomyces hainanensis YIM $47672^{\top}$ (97.8\%) and Streptomyces cacaoi subsp. cacaoi NBRC $12748^{\top}(97.5 \%)$. Strain GW41-1564 ${ }^{\top}$ could be distinguished from any other Streptomyces species with validly published names by sequence similarity values less than $97.5 \%$. Strain GW41-1564 ${ }^{\top}$ exhibited an unusual quinone system, with the predominant compounds $\mathrm{MK}-10\left(\mathrm{H}_{4}\right)$ and $\mathrm{MK}-10\left(\mathrm{H}_{6}\right)$ and smaller amounts of MK-9 $\left(\mathrm{H}_{4}\right)$ and MK-9 $\left(\mathrm{H}_{6}\right)$. The type strain of the most closely related species, S. hainanensis YIM $47672^{\top}$, also contained an unusual quinone system composed of $M K-9\left(\mathrm{H}_{6}\right)$ and $\mathrm{MK}-9\left(\mathrm{H}_{8}\right)$ in addition to $\mathrm{MK}-9\left(\mathrm{H}_{4}\right)$ and $\mathrm{MK}-10\left(\mathrm{H}_{0}\right)$, whereas the type strain of the second most closely related species, S. cacaoi NBRC $12748^{\top}$, contained a quinone system, composed of MK-9 $\left(\mathrm{H}_{6}\right)$ and MK$9\left(\mathrm{H}_{8}\right)$, typical of Streptomyces. The polar lipid profile of GW41-1564 ${ }^{\top}$ consisted of the predominant compound diphosphatidylglycerol, moderate amounts of phosphatidylethanolamine, phosphatidylglycerol and phosphatidylinositol and minor to trace amounts of two phosphatidylinositol mannosides and several unknown lipids, and the major fatty acids were iso$\mathrm{C}_{16: 0 \text {, anteiso- }} \mathrm{C}_{17: 1} \omega 9 \mathrm{c}$ and anteiso- $\mathrm{C}_{17: 0}$. The results of physiological and biochemical tests allowed further phenotypic differentiation of strain $\mathrm{GW} 41-1564^{\top}$ from the related species $S$. hainanensis. Strain GW41-1564 ${ }^{\top}$ clearly merits species status, and we propose the name Streptomyces specialis sp. nov., with the type strain GW41-1564 ${ }^{\top}$ (=DSM $41924^{\top}=\mathrm{CCM}$ $\left.7499^{\top}\right)$.
The genus Streptomyces, proposed by Waksman \& Henrici (1943), currently encompasses nearly 600 species with validly published names. Streptomyces species are aerobic, Gram-positive actinomycetes and most of them are able to form an extensively branched substrate mycelium and also to produce aerial hyphae that typically differentiate into chains of spores. Streptomyces species have LL-diaminopimelic acid but no characteristic sugars in the cell wall (wall chemotype 1 sensu Lechevalier \& Lechevalier, 1970) and possess DNA rich in G + C (Williams et al., 1983; Manfio et al., 1995). Although some authors have found some evidence that the genus is underspeciated (Sembiring et al., 2000; Kim \& Goodfellow, 2002), the major problem in describing novel species is the high 16S rRNA gene sequence similarity. Kämpfer \& Labeda (2006) pointed out that, although 16S rRNA gene sequence data should be

The GenBank/EMBL/DDBJ accession number for the 16S rRNA gene sequence of strain GW41-1564 ${ }^{\top}$ is AM934703. used as a framework for presentation of species and species groups, the boundary for species delineation in this genus seems to be higher than $97 \%$. As a consequence, $16 \mathrm{~S}$ rRNA gene sequence data cannot serve as the sole basis for species delineation within the genus Streptomyces, and the problems of the insufficient resolution capacity of this molecule are evident. In particular, conclusions derived from 'simple' treeing methods (like the neighbour-joining method) should be regarded with caution, given that a tree is only a visual aid to place a novel species in its approximate neighbourhood. The judgement of what is a species and which are its closest relatives should be made on the basis of individual sequence similarities, rather than the position of a sequence in a tree.

In this regard, it was agreed earlier (Kämpfer \& Labeda, 2003) that the proposal of novel species within the genus Streptomyces should only be accepted on the basis of very careful studies done with sufficient practice and considering all other species. However, this is almost impossible, 
given the large number of species. The description of Streptomyces species must be based on a combination of genotypic and phenotypic data (Manfio et al., 1995, 2003; Atalan et al., 2000; Li et al., 2002) and, if sufficient evidence is provided that an unknown is clearly different in both genotypic and phenotypic features, novel species can be described.

During the characterization of organisms isolated from different soils, strain GW41-1564 ${ }^{\mathrm{T}}$ was recovered from $1 \mathrm{~g}$ of a soil sample on mannitol-rifampicin agar [containing $\left(\mathrm{l}^{-1}\right)$ : mannitol, $10 \mathrm{~g}$; yeast extract, $7 \mathrm{~g}$; Casamino acids, $2 \mathrm{~g} ;$ peptone (Bacto), $1 \mathrm{~g} ; \mathrm{NaCl}, 1 \mathrm{~g} ; \mathrm{CaCO}_{3}, 0.2 \mathrm{~g}$; nystatin, $100 \mathrm{mg}$; rifampicin, $5 \mathrm{mg}$ ] for 6 weeks at $27^{\circ} \mathrm{C}$. The strain was maintained on DSMZ medium 65 (http:// www.dsmz.de/media/med065.htm) at $25{ }^{\circ} \mathrm{C}$ and showed a pale-yellow-coloured substrate mycelium that fragmented easily into irregular rod-shaped cells. The isolate grew well on all tested ISP media (ISP1-5; Shirling \& Gottlieb, 1966) after 2 weeks incubation at $28{ }^{\circ} \mathrm{C}$. On all media, a pinkishwhite aerial mycelium and a pale-yellow substrate mycelium were produced. The isolate produced a black pigment on all tested ISP media. Cell morphology was observed under a Zeiss light microscope at $\times 1000$, with cells grown for 3 days at $25{ }^{\circ} \mathrm{C}$ on DSMZ medium 65. The strain was Gram-positive with the staining procedure of Gerhardt et al. (1994). Spores were elliptical or short rods (Fig. 1).

The 16S rRNA gene was analysed as described by Kämpfer et al. (2003). Sequence analysis was performed using the ARB software package (Ludwig et al., 2004) and also the software package MEGA version 2.1 (Kumar et al., 2001) after multiple alignment of data by CLUSTAL_x (Thompson et al., 1997). Distances were calculated (distance options according to the Kimura-2 model) and clustering with the

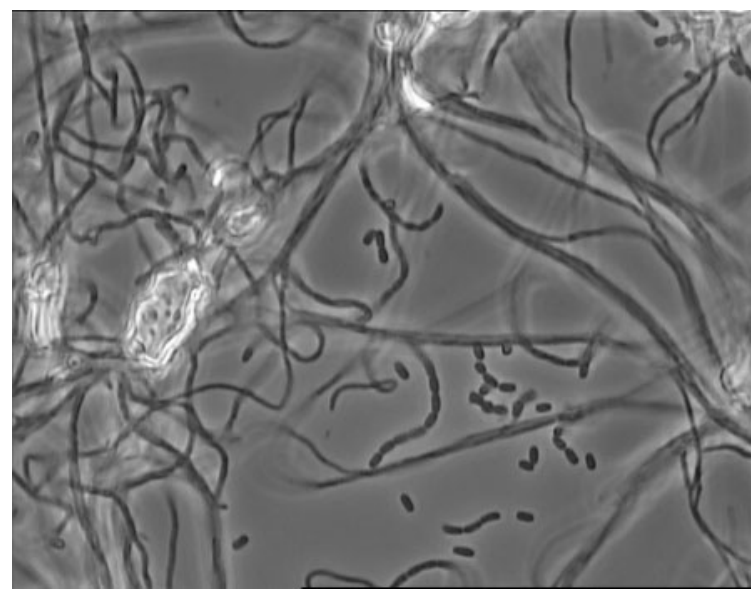

Fig. 1. Micrograph of strain GW41-1564 ${ }^{\top}$ showing curved chains of spores after 3 weeks growth at $30{ }^{\circ} \mathrm{C}$ on DSMZ medium 65 . Spore length is approximately $1 \mu \mathrm{m}$. neighbour-joining, maximum-parsimony and maximumlikelihood algorithms was performed by using bootstrap values based on 1000 replications. The almost-complete $16 \mathrm{~S}$ rRNA gene sequences of all strains were compared by sequence similarity calculations after a neighbour-joining analysis (Saitou \& Nei, 1987). The results of these calculations indicated that the closest relatives of strain GW41-1564 ${ }^{\mathrm{T}}$ were Streptomyces hainanensis YIM $47672^{\mathrm{T}}$ $(97.8 \%)$ and Streptomyces cacaoi subsp. cacaoi NBRC $12748^{\mathrm{T}}(97.5 \%)$. All other Streptomyces species showed lower sequence similarity to strain GW41-1564 ${ }^{\mathrm{T}}$ $(<97.5 \%)$. With all treeing methods, strain GW41-1564 ${ }^{\mathrm{T}}$ clustered clearly with S. hainanensis YIM $47672^{\mathrm{T}}$. S. cacaoi subsp. cacaoi and other related species like Streptomyces aminophilus, S. violaceusniger, S. yogyakartensis and S. hygroscopicus were found in adjacent clusters. A maximumlikelihood tree is shown in Fig. 2. S. hainanensis was described by Jiang et al. (2007); this species was also described as occupying a unique position in the $16 \mathrm{~S}$ rRNA gene sequence-based tree. S. cacaoi subsp. cacaoi was shown to be an earlier heterotypic synonym of S. aminophilus (Lanoot et al., 2002). Because of the low 16S rRNA gene sequence similarity of GW41-1564 ${ }^{\mathrm{T}}$ to other Streptomyces species, S. cacaoi subsp. cacaoi DSM $40057^{\mathrm{T}}$ was included in a comparative study. However, DNA-DNA hybridization studies were not carried out between strain GW41$1564^{\mathrm{T}}$ and these organisms, as representatives of other pairs of Streptomyces species with similarly low $16 \mathrm{~S}$ rRNA gene sequence similarities (Sembiring et al., 2000; Kim \& Goodfellow, 2002; Manfio et al., 2003) show relatedness values below the $80 \%$ cut-off point recommended for the recognition of genomic species of Streptomyces (Labeda \& Lyons, 1992; Labeda, 1993, 1998).

For quinone and polar lipid analyses, cells were grown in liquid DSMZ medium 65 until the majority of the $\mathrm{CaCO}_{3}$ was resolved. Menaquinones were extracted as described by Tindall (1990a) and analysed by HPLC according to Stolz et al. (2007) and extraction and analysis of polar lipids was performed as described by Tindall (1990b). Strain GW41$1564^{\mathrm{T}}$ exhibited a quinone system with the predominant compounds MK-10 $\left(\mathrm{H}_{4}\right)$, MK-10 $\left(\mathrm{H}_{6}\right)$, MK-9 $\left(\mathrm{H}_{4}\right)$, MK$9\left(\mathrm{H}_{6}\right)$ and $\mathrm{MK}-10\left(\mathrm{H}_{8}\right)$ in the ratio $58: 16: 15: 4: 3$. Minor amounts $(<2 \%)$ of MK-10, MK- $10\left(\mathrm{H}_{2}\right)$ and MK-11 $\left(\mathrm{H}_{6}\right)$ were also detected. Analysis of an independently grown biomass of GW41-1564 ${ }^{\mathrm{T}}$ resulted in a similar quinone system, also consisting of the major compounds MK$10\left(\mathrm{H}_{4}\right), \mathrm{MK}-10\left(\mathrm{H}_{6}\right)$, MK- $9\left(\mathrm{H}_{4}\right)$ and MK- $9\left(\mathrm{H}_{6}\right)$ in the ratio $61: 24: 8: 6$. The quinone system of $S$. cacaoi subsp. cacaoi DSM $40057^{\mathrm{T}}$ consisted of MK- $9\left(\mathrm{H}_{6}\right)$ and MK- $9\left(\mathrm{H}_{8}\right)$ in the ratio 53:35 and minor amounts $(<10 \%)$ of MK- $8\left(\mathrm{H}_{6}\right)$ and MK-9 $\left(\mathrm{H}_{2}\right)$. S. hainanensis YIM $47672^{\mathrm{T}}$ also contained an unusual quinone system, composed of MK-9 $\left(\mathrm{H}_{6}\right)$ and MK-9 $\left(\mathrm{H}_{8}\right)$ in addition to MK-9 $\left(\mathrm{H}_{4}\right)$ and $\mathrm{MK}-10\left(\mathrm{H}_{0}\right)$ (Jiang et al., 2007), which is atypical in comparison with those reported for other Streptomyces species.

The polar lipid profile of strain GW41-1564 ${ }^{\mathrm{T}}$ consisted of the major compound diphosphatidylglycerol, moderate 


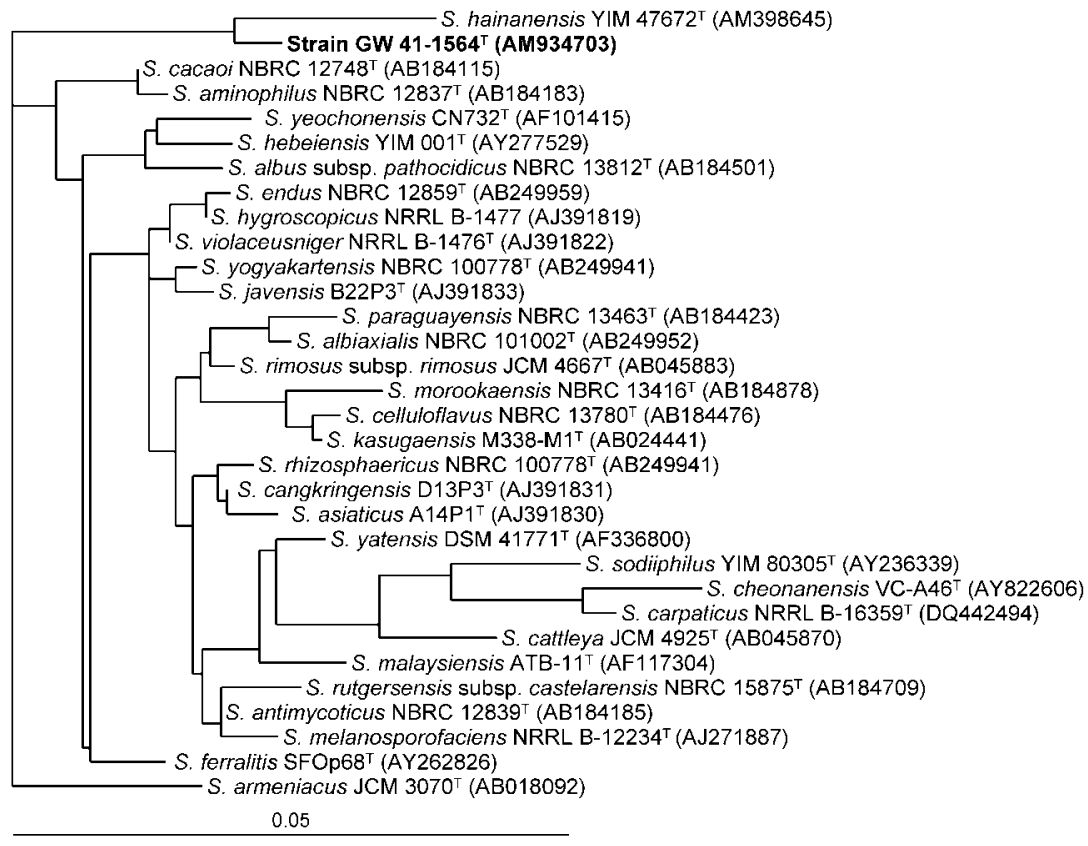

Fig. 2. Phylogenetic analysis of selected Streptomyces species most closely related to strain GW41-1564 ${ }^{\top}$ based on 16S rRNA gene sequences available from the EMBL database (accession numbers in parentheses) constructed after multiple alignment of data by the ARB program and CLUSTAL_X (Thompson et al., 1997). Clustering with the maximumlikelihood method was performed by using the ARB software package (Ludwig et al., 2004). amounts of phosphatidylethanolamine, phosphatidylglycerol and phosphatidylinositol and minor to trace amounts of two phosphatidylinositol mannosides, of which one was visible only after $\alpha$-naphthol detection and not after detection with molybdatophosphoric acid, one unknown phospholipid, one unknown aminolipid and three unknown polar lipids (Fig. 3). The profile corresponds to phospholipid type 2 (Lechevalier et al., 1977; Minnikin et al., 1977), and similar profiles have been reported for numerous Streptomyces species.

Fatty acid analysis was performed according to Kämpfer \& Kroppenstedt (1996). The fatty acid profile of strain GW41-1564 ${ }^{\mathrm{T}}$ was clearly different from those of $S$. hainanensis YIM $47672^{\mathrm{T}}$ and $S$. cacaoi subsp. cacaoi DSM $40057^{\mathrm{T}}$ (Table 1), and showed many fatty acids in smaller amounts that are not found in most other Streptomyces species (Kämpfer, 2006).

Results of the physiological characterization showed that strain GW41-1564 ${ }^{\mathrm{T}}$ is able to utilize few carbon sources. Detailed results of the physiological characterization (according to Kämpfer et al., 1991) are given in the species description, and a summary of differentiating tests from most closely related species is shown in Table 2 .

It is evident that strain GW41-1564 ${ }^{\mathrm{T}}$ is clearly different from all other Streptomyces species. It shares less than $97.8 \%$ 16S rRNA gene sequence similarity with other streptomycetes and it can be distinguished phenotypically/ chemotaxonomically from its nearest relatives $S$. hainanensis and $S$. cacaoi based on striking differences in the fatty acid profile, regarding the absence/presence of iso$\mathrm{C}_{14: 0}$ and iso- $\mathrm{C}_{16: 1} \mathrm{H}$ and significant quantitative differences in the contents of iso- $C_{15: 0}$, anteiso- $C_{15: 0}$ and anteiso- $\mathrm{C}_{17: 1} \omega 9 c$, and the quinone system, with MK-10 derivatives predominating, which is unique to date among streptomycetes. For this reason, we describe a novel species, for which we propose the name Streptomyces specialis sp. nov.

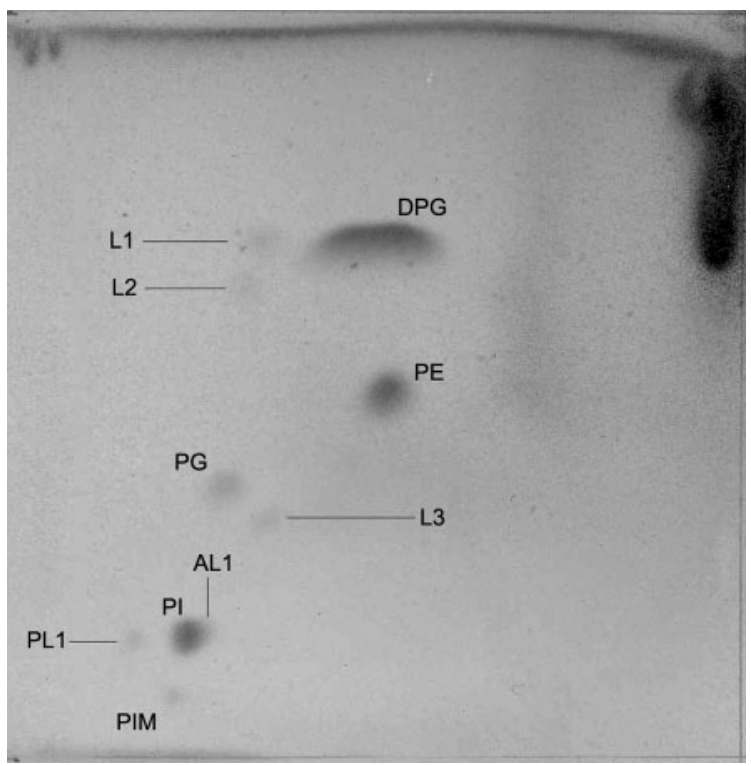

Fig. 3. Polar lipid profile of GW41-1564 ${ }^{\top}$ after two-dimensional TLC and detection with molybdatophosphoric acid. PE, Phosphatidylethanolamine; DPG, diphosphatidylglycerol; PG, phosphatidylglycerol; PI, phosphatidylinositol; PIM, phosphatidylinositol mannoside; PL1, unknown phospholipid; AL1, unknown aminolipid; L1-3, unknown polar lipids. 
Table 1. Major fatty acids (\%) of type strains of species of the genus Streptomyces that grouped into the same cluster on the basis of $16 \mathrm{~S}$ rRNA gene sequence similarity

Strains: 1, GW41-1564 ${ }^{\mathrm{T}}$; 2, S. hainanensis YIM $47672^{\mathrm{T}}, 3$, S. cacaoi subsp. cacaoi DSM $40057^{\mathrm{T}}$. Strains GW41-1564 ${ }^{\mathrm{T}}$ and DSM $40057^{\mathrm{T}}$ were grown on trypticase soy broth at $28{ }^{\circ} \mathrm{C}$ for 7 days prior to fatty acid analysis. Data for S. hainanensis YIM $47672^{\mathrm{T}}$ were from Jiang et al. (2007); the strain was grown under identical conditions prior to fatty acid analysis (Kämpfer \& Kroppenstedt, 1996). For unsaturated fatty acids, the position of the double bond is located by counting from the methyl $(\omega)$ end of the carbon chain; capital letters indicate unidentified double-bond positions and cis isomers are indicated by the suffix $c$. - , Not detected; NR, not reported.

\begin{tabular}{|c|c|c|c|}
\hline Fatty acid & 1 & 2 & 3 \\
\hline $\mathrm{C}_{15: 0}$ & 0.2 & $\mathrm{NR}$ & 3.6 \\
\hline $\mathrm{C}_{16: 0}$ & 3.5 & 13.7 & 4.1 \\
\hline $\mathrm{C}_{17: 0}$ & 0.2 & 5.6 & 1.0 \\
\hline $\mathrm{C}_{18: 0}$ & 0.3 & 1.2 & - \\
\hline iso- $\mathrm{C}_{14: 0}$ & - & NR & 6.5 \\
\hline iso- $\mathrm{C}_{15: 0}$ & 0.6 & 1.1 & 6.9 \\
\hline anteiso- $\mathrm{C}_{15: 0}$ & 1.5 & NR & 32.1 \\
\hline anteiso- $\mathrm{C}_{15: 1} \mathrm{~A}$ & - & NR & 1.3 \\
\hline iso- $\mathrm{C}_{15: 1} \mathrm{G}$ & - & NR & 0.6 \\
\hline iso- $\mathrm{C}_{16: 1} \mathrm{G}$ & - & NR & 1.6 \\
\hline iso- $\mathrm{C}_{16: 1} \mathrm{H}$ & 8.0 & $\mathrm{NR}$ & - \\
\hline iso- $\mathrm{C}_{16: 0}$ & 33.1 & 30.9 & 24.3 \\
\hline iso- $\mathrm{C}_{17: 0}$ & 1.2 & 2.8 & 3.6 \\
\hline anteiso- $\mathrm{C}_{17: 0}$ & 26.4 & 10.8 & 12.5 \\
\hline iso- $\mathrm{C}_{18: 1} \mathrm{H}$ & 0.4 & $\mathrm{NR}$ & - \\
\hline iso- $\mathrm{C}_{18: 0}$ & 0.4 & NR & - \\
\hline $\mathrm{C}_{17: 0}$ cyclo & 0.7 & 1.4 & - \\
\hline $\mathrm{C}_{17: 1} \omega 8 c$ & 0.7 & 7.1 & - \\
\hline iso- $\mathrm{C}_{17: 1} \omega 9 c$ & 1.5 & 1.4 & - \\
\hline anteiso- $\mathrm{C}_{17: 1} \omega 9 c$ & 11.2 & NR & 1.1 \\
\hline $\mathrm{C}_{18: 1} \omega 9 c$ & 1.3 & 4.9 & - \\
\hline Summed feature $3^{*}$ & 3.3 & 2.1 & - \\
\hline Summed feature $5^{\star}$ & 4.5 & 9.7 & 0.5 \\
\hline $\mathrm{C}_{17: 0} 10$-methyl & 1.2 & NR & - \\
\hline
\end{tabular}

* Summed features are groups of two or three fatty acids that cannot be separated by GLC with the MIDI system. Summed feature 3 contained $\mathrm{C}_{16: 1} \omega 7 c$ and/or iso- $\mathrm{C}_{15: 0}$ 2-OH. Summed feature 5 contained $\mathrm{C}_{18: 2} \omega 6,9 c$ and/or anteiso- $\mathrm{C}_{18: 0}$.

\section{Description of Streptomyces specialis sp. nov.}

Streptomyces specialis (spe.ci.a'lis. L. masc. adj. specialis particular, special, because of the unusual quinone type and the separate phylogenetic position).

Aerobic, Gram-positive actinomycete that forms an extensively branched substrate mycelium and aerial hyphae that differentiate into spiral chains of spores. Spore chains consist of up to 15 spores. Spores are elliptical or short rods (Fig. 1). Grows well on all tested ISP media (ISP1-5; Shirling \& Gottlieb, 1966) after 2 weeks incubation at $28{ }^{\circ} \mathrm{C}$. On all media, a pinkish white aerial mycelium and a
Table 2. Physiological characteristics of strain GW41-1564 ${ }^{\top}$ and the type strains of Streptomyces species showing $16 \mathrm{~S}$ rRNA gene sequence similarity $>96.5 \%$

Strains: 1, GW41-1564 ${ }^{\mathrm{T}} ; 2$, S. cacaoi subsp. cacaoi NBRC $12748^{\mathrm{T}} ; 3$, S. yogyakartensis NBRC $100778^{\mathrm{T}} ; 4$, S. hygroscopicus NRRL $2387^{\mathrm{T}} ; 5$, S. violaceusniger NRRL B- $1478^{\mathrm{T}} ; 6$, S. hainanensis YIM $47672^{\mathrm{T}} .+$, Positive; -, negative; (+) weakly positive; ND, no data available. Test results for S. yogyakartensis NBRC $100778^{\mathrm{T}}$, S. hygroscopicus NRRL $2387^{\mathrm{T}}$ and S. violaceusniger NRRL B-1478 ${ }^{\mathrm{T}}$ were taken from Goodfellow et al. (2007) and results for S. hainanensis YIM $47672^{\mathrm{T}}$ were taken from Jiang et al. (2007).

\begin{tabular}{|lcccccc|}
\hline Test & $\mathbf{1}$ & $\mathbf{2}$ & $\mathbf{3}$ & $\mathbf{4}$ & $\mathbf{5}$ & $\mathbf{6}$ \\
\hline Production of: & & & & & & \\
$\quad \beta$-D-Galactosidase & - & $\mathrm{ND}$ & + & - & + & $\mathrm{ND}$ \\
$\beta$-D-Glucosidase & $(+)$ & + & - & - & + & $\mathrm{ND}$ \\
Aesculin hydrolysis & - & + & + & + & + & + \\
Growth on sole carbon sources & & & & & & \\
$\quad$ Adonitol & + & - & + & - & + & - \\
L-Arabinose & - & - & + & - & + & - \\
Cellobiose & - & + & + & + & + & + \\
Dulcitol & - & $\mathrm{ND}$ & - & - & - & $\mathrm{ND}$ \\
D-Fructose & + & - & + & + & - & - \\
Melezitose & - & - & + & - & - & - \\
Salicin & + & $\mathrm{ND}$ & + & - & + & - \\
D-Sorbitol & $(+)$ & - & - & - & - & - \\
& & & & & & \\
\hline
\end{tabular}

pale yellow substrate mycelium are produced. Produces a black pigment on all tested ISP media. Good growth occurs on nutrient agar and DSMZ medium 65 at $25-30{ }^{\circ} \mathrm{C}$. Major fatty acids are iso- $\mathrm{C}_{16: 0}, \mathrm{C}_{16: 0}$, anteiso- $\mathrm{C}_{17: 1} \omega 9 c$, anteiso- $\mathrm{C}_{17: 0}$ and iso- $\mathrm{C}_{16: 1} \mathrm{H}$. The quinone system is composed of the major compound $\mathrm{MK}-10\left(\mathrm{H}_{4}\right)$ and moderate to minor amounts of MK-10 $\left(\mathrm{H}_{6}\right), \mathrm{MK}-9\left(\mathrm{H}_{4}\right)$ and MK-9 $\left(\mathrm{H}_{6}\right)$. In the polar lipid profile, diphosphatidylglycerol is predominant. Phosphatidylethanolamine, phosphatidylglycerol and phosphatidylinositol are present in moderate amounts and phosphatidylinositol mannosides, an unknown aminolipid, an unknown phospholipid and three unknown polar lipids are present in minor to trace amounts. The following carbon sources are utilized: $\mathrm{N}$ acetyl-D-glucosamine, D-glucose, D-gluconate, D-ribose, sucrose, adonitol, D-arabitol, D-sorbitol, myo-inositol, propionate, glutarate, butyrate, isobutyrate, isovaleric acid, $\mathrm{L}$-arginine and $\mathrm{L}$-asparagine. The following carbon sources are not utilized: L-arabinose, cellobiose, D-fructose, Dgalactose, maltose, D-mannose, melibiose, L-rhamnose, salicin and D-xylose.

The type strain, GW41-1564 ${ }^{\mathrm{T}}\left(=\mathrm{DSM} 41924^{\mathrm{T}}=\mathrm{CCM}\right.$ $\left.7499^{\mathrm{T}}\right)$, was isolated from soil.

\section{References}

Atalan, E., Manfio, G. P., Ward, A. C., Kroppenstedt, R. M. \& Goodfellow, M. (2000). Biosystematic studies on novel streptomyces from soil. Antonie van Leeuwenhoek 77, 337-353. 
Gerhardt, P., Murray, R. G. E., Wood, W. A. \& Krieg, N. R. (editors) (1994). Methods for General and Molecular Bacteriology. Washington, DC: American Society for Microbiology.

Goodfellow, M., Kumar, Y., Labeda, D. P. \& Sembiring, L. (2007). The Streptomyces violaceusniger clade: a home for streptomycetes with rugose ornamented spores. Antonie van Leeuwenhoek 92, 173-199.

Jiang, Y., Tang, S.-K., Wiese, J., Xu, L.-H., Imhoff, J. F. \& Jiang, C.-L. (2007). Streptomyces hainanensis sp. nov., a novel member of the genus Streptomyces. Int J Syst Evol Microbiol 57, 2694-2698.

Kämpfer, P. (2006). The family Streptomycetaceae. Part I. Taxonomy. In The Prokaryotes: a Handbook on the Biology of Bacteria, 3rd edn, vol. 3, pp. 538-604. Edited by M. Dworkin, S. Falkow, E. Rosenberg, K. H. Schleifer \& E. Stackebrandt. New York: Springer.

Kämpfer, P. \& Kroppenstedt, R. M. (1996). Numerical analysis of fatty acid patterns of coryneform bacteria and related taxa. Can J Microbiol 42, 989-1005.

Kämpfer, P. \& Labeda, D. P. (2003). International Committee on Systematics of Prokaryotes Subcommittee on the taxonomy of Streptomycetaceae. Minutes of the meeting, 30 July 2002, Paris, France. Int J Syst Evol Microbiol 53, 925.

Kämpfer, P. \& Labeda, D. P. (2006). International Committee on Systematics of Prokaryotes Subcommittee on the taxonomy of the Streptomycetaceae. Minutes of the meeting, 25 July 2005, San Francisco, CA, USA. Int J Syst Evol Microbiol 56, 495.

Kämpfer, P., Kroppenstedt, R. M. \& Dott, W. (1991). A numerical classification of the genera Streptomyces and Streptoverticillium using miniaturized physiological tests. J Gen Microbiol 137, 1831-1891.

Kämpfer, P., Dreyer, U., Neef, A., Dott, W. \& Busse, H.-J. (2003). Chryseobacterium defluvii sp. nov., isolated from wastewater. Int J Syst Evol Microbiol 53, 93-97.

Kim, S. B. \& Goodfellow, M. (2002). Streptomyces thermospinisporus sp. nov., a moderately thermophilic caboxydotrophic streptomycete isolated from soil. Int J Syst Evol Microbiol 52, 1225-1228.

Kumar, S., Tamura, K., Jakobsen, I.-B. \& Nei, M. (2001). MEGA2: molecular evolutionary genetics analysis software. Bioinformatics 17, 1244-1245.

Labeda, D. P. (1993). DNA relatedness among strains of the Streptomyces lavendulae phenotypic cluster group. Int $J$ Syst Bacteriol 43, 822-825.

Labeda, D. P. (1998). DNA relatedness among the Streptomyces fulvissimus and Streptomyces griseoviridis phenotypic cluster groups. Int J Syst Bacteriol 48, 829-832.

Labeda, D. P. \& Lyons, A. J. (1992). DNA relatedness among strains of the sweet potato pathogen Streptomyces ipomoea (Person and Martin 1940) Waksman and Henrici 1948. Appl Environ Microbiol 58, 532535.

Lanoot, B., Vancanneyt, M., Cleenwerck, I., Wang, L., Li, W., Liu, Z. \& Swings, J. (2002). The search for synonyms among streptomycetes by using SDS-PAGE of whole-cell proteins. Emendation of the species Streptomyces aurantiacus, Streptomyces cacaoi subsp. cacaoi,
Streptomyces caeruleus and Streptomyces violaceus. Int J Syst Evol Microbiol 52, 823-829.

Lechevalier, M. P. \& Lechevalier, H. A. (1970). Chemical composition as a criterion in the classification of aerobic actinomycetes. Int J Syst Bacteriol 20, 435-443.

Lechevalier, M. P., De Bièvre, C. \& Lechevalier, H. A. (1977). Chemotaxonomy of aerobic actinomycetes: phospholipid composition. Biochem Syst Ecol 5, 249-260.

Li, W., Lanoot, B., Zhang, Y., Vancanneyt, M., Swings, J. \& Liu, Z. (2002). Streptomyces scopiformis sp. nov., a novel streptomycete with fastigiated spore chains. Int J Syst Evol Microbiol 52, 1629-1633.

Ludwig, W., Strunk, O., Westram, R., Richter, L., Meier, H., Yadhukumar, Buchner, A., Lai, T., Steppi, S. \& other authors (2004). ARB: a software environment for sequence data. Nucleic Acids Res 32, 1363-1371.

Manfio, G. P., Zakrzewska-Czerwinska, J., Atalan, E. \& Goodfellow, M. (1995). Towards minimal standards for the description of Streptomyces species. Bioteknologia 7-8, 242-253.

Manfio, G. P., Atalan, E., Zakrzewska-Czerwinska, J., Mordarski, M., Rodriguez, C., Collins, M. D. \& Goodfellow, M. (2003). Classification of novel soil streptomycetes as Streptomyces aureus sp. nov., Streptomyces laceyi sp. nov. and Streptomyces sanglieri sp. nov. Antonie van Leeuwenhoek 83, 245-255.

Minnikin, D. E., Patel, P. V., Alshamaony, L. \& Goodfellow, M. (1977). Polar lipid composition in the classification of Streptomyces and related bacteria. Int J Syst Bacteriol 27, 104-117.

Saitou, N. \& Nei, M. (1987). The neighbor-joining method: a new method for reconstructing phylogenetic trees. Mol Biol Evol 4, 406-425.

Sembiring, L., Ward, A. C. \& Goodfellow, M. (2000). Selective isolation and characterization of members of the Streptomyces violaceusniger clade associated with roots of Paraserianthes falcataria. Antonie van Leeuwenhoek 78, 353-366.

Shirling, E. B. \& Gottlieb, D. (1966). Methods for characterization of Streptomyces species. Int J Syst Bacteriol 16, 313-340.

Stolz, A., Busse, H.-J. \& Kämpfer, P. (2007). Pseudomonas knackmussii sp. nov. Int J Syst Evol Microbiol 57, 572-576.

Thompson, J. D., Gibson, T. J., Plewniak, F., Jeanmougin, F. \& Higgins, D. G. (1997). The CLUSTAL_X windows interface: flexible strategies for multiple sequence alignment aided by quality analysis tools. Nucleic Acids Res 25, 4876-4882.

Tindall, B. J. (1990a). A comparative study of the lipid composition of Halobacterium saccharovorum from various sources. Syst Appl Microbiol 13, 128-130.

Tindall, B. J. (1990b). Lipid composition of Halobacterium lacusprofundi. FEMS Microbiol Lett 66, 199-202.

Waksman, S. A. \& Henrici, A. T. (1943). The nomenclature and classification of the actinomycetes. J Bacteriol 46, 337-341.

Williams, S. T., Goodfellow, M., Alderson, G., Wellington, E. M. H., Sneath, P. H. A. \& Sackin, M. J. (1983). Numerical classification of Streptomyces and related genera. J Gen Microbiol 129, 1742-1813. 